\title{
JUNIOR SECONDARY SCHOOL STUDENTS' INTRALINGUAL ERRORS IN ESSAYS WRITTEN IN FRENCH LANGUAGE
}

\author{
S. M. UMOH AND P. C. N. EZENWA \\ (Received 2, October 2020; Revision Accepted 6, November 2020)
}

\begin{abstract}
This study set out to identify students' intralingual errors in the essays written in French. The study adopted the ex-post facto design, using the content analysis technique. The population comprised 2,893 copies of descriptive essays written in French Language by year 3 junior secondary school students in the Basic Education Certificate Examination (BECE) in 2015, 2016 and 2017 in Imo State. The sample of 228 essays was selected through stratified, purposive and proportionate random sampling techniques. The three instruments for the study were the question papers on French Language, the students' answer scripts and a researcher-designed Checklist of Intralingual Errors for Learning French (CIELF). The data from the error analysis were subjected to analysis using the Statistical Package for the Social Sciences (SPSS) and the research question that guided the study was answered in percentages. The results showed that the students committed eight intralingual errors, which include overgeneralization, omission, addition, simplification of parts of speech, misinformation, agreement, verb forms and mechanical errors. Part of the recommendations is for teachers of French to build language instructions on students' prior knowledge and experiences, thereby making French language learning to be real and interesting to the students.
\end{abstract}

KEYWORDS: French language learning, Intralingual errors, Error Analysis

\section{INTRODUCTION}

The ability to speak French by Nigerians is hoped to enhance economic development especially in the areas of career development, tourism, cultural integration and economic enterprises. No wonder the Federal Ministry of Education (2012) set out to enable the students to learn and speak French and meaningfully communicate in the language, by reviewing and publishing the curriculum for the teaching of French in the junior secondary schools. The government stresses that the review was in view of a better acquisition of the competences that will enable the students to truly use the French language as a tool for communication by the end of the junior secondary school level. In the use of the new syllabus, the competences to be acquired by
Nigerian learners of French are the language skills of listening, speaking, reading and writing. However, it is observed that students have difficulties acquiring the expected language skills in French and so are not able to communicate meaningfully in French language at the end of their junior secondary school. Their efforts to speak or write in French are fraught with a lot of errors, as evidenced in their performance in examinations like the end-programme examination, the Basic Education Certificate Examination (BECE) in which most students' performance in French is not satisfactory as most students pass the language below Credit level. Usually, in the BECE, the presence of errors contributes in determining the students' performance, especially in their written essays. The Examination Development Centre, Owerri

S. M. Umoh, Arts Education Department, University of Calabar

P. C. N. Ezenwa, Department of Language Education, Imo State University, Owerri

() 2020 Bachudo Science co. Ltd. This work is Licensed Under Creative Commons Attribution 4.0 international license. 
(2018) states that the total score for the essay in French Language is 20 marks and the distribution of the scores in the marking guide are as follows: content, 5 marks; organization, 3 marks; expression, 7 marks; mechanical accuracy, 3 marks and conclusion, 2 marks. From the marking guide, expression and mechanical accuracy carry half of the scores in the essay, 7 marks and 3 marks respectively, giving a total of 10 marks. Also, it is these two areas that will highlight the students' errors in the use of the French language. This implies that, to a great extent, the students' errors in these areas will determine their performance in French Language in the Basic Education Certificate Examination (BECE).

Errors are a common phenomenon in the language learning process, especially for second or foreign language learning. Ellis (2010) asserts that an error is a noticeable deviation from the adult grammar of a native speaker. This deviation is noticed in the second or foreign language learner's usage and reflects the competence of the learner. Shaffer (2009) observes that errors are an important ingredient in the language learning process as they provide feedback for the language learner and give important insight into the processes governing second language acquisition. Hence, in carrying out the evaluation of students' language learning, teachers usually observe different types of errors and at varying degrees. The more the errors, the less the students must have learnt and the more efforts they need to make in order to learn.

Despite the various classifications of errors, this study was interested in intralingual errors as identified by Glottopedia (2009), that recognizes intralingual errors as coming from learners' difficulties in learning a target language. It recognizes intralingual errors as occurring, for example, when a target language rule is applied to areas where it is not applicable. Hence, intralingual errors are errors that revolve around the learners' situations of language learning and their efforts in using the target language. In the process of making efforts to use a second language, learners may use the target language in ways that do not conform to the native speakers' norm. Intralingual errors are those different ways that learners fail to measure up to the native speakers' norm, as a result of the difficulties encountered due to the nature of the target language.

There are different sub-types of intralingual errors, which could be due to overgeneralization or ignorance of rules restriction or due to the false concept hypothesis. The classifications reflect the various difficulties encountered by learners as they learn the target language as well as the strategies that they develop in handling their difficulties. Examples of intralingual errors for English-speaking learners of French include overgeneralization, omission, addition, irregular verbs, agreement of verbs not only with the subjects of a sentence but also with the object and so on. A typical example of such intralingual errors is for an English-speaking learner of French to say or write Nous mangons instead of Nous mangeons (literally, we eat/we are eating). The learner must have learnt the language rule that for the first person plural, an ER-ending verb like parler (to speak), danser (to dance), adds ons to the root. Examples, for parler, nous parlons (we speak), for danser, nous dansons (we dance). For the learner, if, for parler, it is nous parlons and for danser, it is nous dansons, then for manger, it should be nous mangons but, it is wrong in French. Rather, it is nous mangeons. The learner's difficulty is that of overgeneralization of the rule, applying it where there is an exception to the rule. There is an exception for ER-ending verbs whose roots end with a $g$ like manger, to add an e to the root before ons. This exception is to soften the sound of the $\mathrm{g}$ and enable the verb to retain the $/ \mathrm{ji} /$ sound.

The presence of intralingual errors could affect the message that learners wish to convey with the target language. Touchie (1986) asserts that overgeneralization is the use of one form or construction in one context and extending its application to other contexts where it should not apply. The author observes that in simplification, learners often choose simple forms and constructions instead of more complex ones. Also, Shaffer (2009) recognizes a classification according to how the surface structure of a sentence or expression is altered by the error and such a classification would include omissions, additions, misinformation and double markings. The author explains that omission is the absence of an important language element that should appear in a well-formed utterance; addition is the presence of an element that should not appear in well-formed utterance and misinformation is the use of the wrong form of the morpheme or structure.

The inability of learners to communicate appropriately as a result of intralingual errors would not be seen as coming from their source language, that is, the language(s) that they already speak, since it is items of the target 
language that are omitted or added or misused. Choroleeva (2009) asserts that intralingual errors are committed regardless of the first language. This does not mean that learners' first language does not matter in their learning of another language. Intralingual errors arise when the difficulties experienced by learners are not as a result of the learners' source language helping them to formulate the hypotheses about the target language. Rather, the difficulties are as a result of the nature of the target language itself. Concerning the language skills, Purcell (2000) asserts that students' success or failure in the writing exercise depends largely on their aptitude in developing an effective system of making a link between the sound and letters of the target language. It is part of the students' efforts to learn the target language especially for activities like writing dictation. This implies that intralingual errors will occur when the students fail to make the proper connection between the sounds and letters of the target language.

In the learning of French, intralingual errors are mostly noticed in learners' mistakes in the use of French grammar. Suzy (2016) identifies mistakes in French grammar which include mostly errors in subject/object agreement, articles, prepositions, negative articles, conjugated verbs and tenses of passé composé/imparfait and subjunct if. Also, Mazet (2017) lists ten common mistakes made in French grammar and include using definite articles incorrectly, confusing indefinite and partitive articles, putting the wrong verb form after avoir or être, mixing up similar verbs like confusing connaître and savoir, dire and parler.

It is not only verbs that have sets that can be confused. Thought Co (2017) identifies the most common mistakes and difficulties among learners of French, even for advanced learners. These include errors in the use of prepositions à and de, indefinite and partitive articles des, du, de la, de l' and des and also reflexive and object pronouns and agreement. In the use of these words and expressions that resemble one another, learners can easily confuse them and, in that way, commit intralingual errors. Fluent Flix Limited (2018) recognizes the major types of errors that Englishspeaking learners of French commit, which include saying ma amie instead of mon ami, mixing up rencontrer and retrouver, confusing pour and pendant, jumbling up c'est and il/elleest and not understanding the difference between penser à and penser de.

Intralingual errors can be observed in students' use of language for oral and written forms of communication in past analyses of students' errors in second and foreign language learning. Presada and La Badea (2014) carried out a pilot study to demonstrate the effectiveness of error analysis within the translation classes. The results of the analysis showed that the most frequent errors included the omission of the subject and the incorrect use of the indicative mood tenses in subordinate clauses. Many examples showed that the students did not master the appropriate usage of tenses in indirect speech. Intralingual errors can also be observed in studies carried out in Nigeria. Jibowo (2002) set out to take a heuristic look at the exact areas in English Language in which some Nigerian undergraduates have problems. The results showed that the undergraduates had problems in the grammar, spelling, punctuation, use of words, use of capital letters and so on.

Given the persistent presence of intralingual errors in the students' French language use, resulting in their continued inability to communicate effectively in French and their resultant poor performance in French Language, the need for research efforts into the students' errors in French becomes imperative. Also, given the status of French as the second official language in Nigeria and the need for the effective teaching and learning of French in Nigerian schools, if the students' errors in French are not identified and properly handled, the students will continue to perform poorly in French. In that case, the aims of including French Language as a core subject in the Nigerian junior secondary school curriculum will not be achieved.

Consequently, the students' errors need to be highlighted and put in proper perspective in order to be handled meaningfully. This justifies the need for the use of error analysis in French language teaching and learning. According to Khansir (2012), the basic task of error analysis is to describe how learning occurs by examining the learners' output and this includes their correct and incorrect utterances both in the oral or written forms of language. The understanding is that if the students' errors can be identified and explained, the information can be adapted to second language pedagogy. Based on this, an analysis of the errors that junior secondary school students of French commit in their essays written in French will help them overcome these errors and improve on their performance in the language. Therefore, this study was aimed at analyzing the intralingual errors that students committed in the essays written in French in the Basic Education Certificate Examination (BECE) in Imo State in 2015, 2016 and 2017. 
RESEARCH METHODOLOGY

This study adopted the ex-post facto research design. This is because, as explained by Idaka and Anagbogu (2012), in ex-post facto design, the phenomena of interest have already occurred and cannot be manipulated in any way. In this study, the errors analyzed were as observed in students' past examination scripts, used in already concluded examinations. In doing this, the study adopted the content analysis technique, which Duriau, Reger and Pfarrer (2007) assert to involve interpreting and coding textual material and is at the intersection of the qualitative and quantitative tradition. Through the analysis of the examination scripts, the study identified and described the different sub-types of students' intralingual errors.

The population of this study comprised 2,893 past examination scripts of descriptive essays written in French by year three junior secondary school students in the Basic Education Certificate Examination (BECE) in Imo State in 2015, 2016 and 2017 in the three main education zones of Imo State namely, Owerri, Orlu and Okigwe zones. There were 1,032 scripts from Owerri zone, 942 scripts from Orlu zone and 919 scripts from Okigwe zone. The sample of 228 copies of essays was drawn using stratified, purposive and proportionate random sampling techniques, representing approximately $10 \%$ of the population.

The three instruments used for the study include the question papers on French Language in the examinations, the scripts bearing the students' essays and a researcher-designed Checklist of Intralingual Errors in Learning French (CIELF). The descriptive essay topics for the years under study include Mon père (My father), Mon pays (My country) and Mon village (My village). The question papers were developed by the Imo State Examination Development Centre (EDC), which is the department in the Imo State Ministry of Education that is charged with the conduct of examinations in the primary and junior secondary schools in the State. The question papers were approved for use by the Imo State Ministry of Education, Owerri for the different years. Therefore, the question papers and answer scripts, as provided by the Examination Development Centre, Owerri, were judged to be valid and reliable.

The Checklist of Intralingual Errors in Learning French (CIELF), is a list of intralingual errors that reflect the areas of difficulties experienced by junior secondary school students in their study of French. In developing the items of the checklist, the researcher made recourse to the errors identified through literature review. The researcher ensured the face validity of the checklist by submitting the draft content of the instrument to the scrutiny of experts in French Language, Language Education and Educational Measurement. Their observations and corrections were reflected in the final version of the checklist. It was also subjected to inter-rater reliability analysis which, according to Huck (2012), establishes the relationship in the assessment made with a test instrument by two or three raters. The researcher carried out the reliability test of the checklist by administering an essay writing test on 15 year three junior secondary school students of Imo Government Girls' Secondary School, Owerri. The essays in French were on the three different essay topics used for the study namely, Mon père, Mon pays and Mon village. The inter-rater reliability indices for the different essay topics were $0.76,0.83$ and 0.87 respectively.

\section{DATA ANALYSIS AND RESULTS}

The analysis of the intralingual errors in the students' essays was carried out using the error checklist designed for the study. The observable intralingual errors in each of the sentences were identified and represented in scores. The data from the error analysis were subjected to computer analysis using the Statistical Package for the Social Sciences (SPSS). The results of the analysis are presented in table 1 . 
Table 1: The intralingual errors in the students' essays

\begin{tabular}{|c|c|c|c|c|c|}
\hline \multicolumn{2}{|l|}{ Error sub-type } & $\mathrm{N}$ error & $\%$ & $\begin{array}{l}N \text { without } \\
\text { error }\end{array}$ & $\%$ \\
\hline \multicolumn{2}{|l|}{ Overgeneralization } & 4 & 1.8 & 224 & 98.2 \\
\hline \multicolumn{2}{|l|}{ Omission } & 116 & 50.9 & 112 & 49.1 \\
\hline \multicolumn{2}{|l|}{ Addition } & 80 & 35.1 & 148 & 64.9 \\
\hline \multirow[t]{7}{*}{$\begin{array}{l}\text { Simplification of parts } \\
\text { of speech }\end{array}$} & $\begin{array}{l}\text { Incorrect use of articles - un, une, le, } \\
\text { la, les }\end{array}$ & 20 & 8.8 & 208 & 91.2 \\
\hline & $\begin{array}{l}\text { Confusing indefinite and partitive } \\
\text { articles - un, une, des, du, de, la, de } \\
\text { l', des }\end{array}$ & 52 & 22.8 & 176 & 77.2 \\
\hline & Using the wrong word for time & 0 & 0 & 228 & 100 \\
\hline & Verbs with prepositions - à, de & 62 & 27.2 & 166 & 72.8 \\
\hline & $\begin{array}{l}\text { Adverbs with prepositions - au, chez, } \\
\text { en }\end{array}$ & 8 & 3.5 & 220 & 96.5 \\
\hline & Misplaced use of avoir, être & 26 & 11.4 & 202 & 88.6 \\
\hline & Total & 110 & 48.2 & 118 & 51.8 \\
\hline \multirow[t]{6}{*}{ Misinformation } & $\begin{array}{l}\text { wrong use of toujours, jamais, } \\
\text { souvent }\end{array}$ & 0 & 0 & 228 & 100 \\
\hline & $\begin{array}{l}\text { Wrong use of beaucoup, un peu, } \\
\text { assez }\end{array}$ & 2 & 0.9 & 226 & 99.1 \\
\hline & $\begin{array}{l}\text { Mixing up of words like rencontrer } \\
\text { and retrouver, pour and pendant, } \\
\text { aimer, preferer }\end{array}$ & 6 & 2.6 & 222 & 97.4 \\
\hline & Jumbling up c'est and il/elleest & 8 & 3.5 & 220 & 96.5 \\
\hline & $\begin{array}{l}\text { Negative forms - ne ... pas, plus, } \\
\text { que, jamais }\end{array}$ & 0 & 0 & 228 & 100 \\
\hline & Total & 56 & 24.6 & 172 & 75.4 \\
\hline \multirow[t]{5}{*}{ Agreement } & Subject/object & 0 & 0 & 228 & 100 \\
\hline & Subject/verb & 0 & 0 & 228 & 100 \\
\hline & Number - singular/plural & 68 & 29.8 & 160 & 70.2 \\
\hline & Gender - masculine/feminine & 100 & 43.9 & 128 & 56.1 \\
\hline & Total & 126 & 55.3 & 102 & 44.7 \\
\hline \multirow{4}{*}{ Verb forms } & Conjugated verbs & 108 & 47.4 & 120 & 52.6 \\
\hline & $\begin{array}{l}\text { Putting the wrong verb form after } \\
\text { auxiliary verb }\end{array}$ & 8 & 3.5 & 220 & 96.5 \\
\hline & Tenses & 12 & 5.3 & 216 & 94.7 \\
\hline & Total & 112 & 49.1 & 116 & 50.9 \\
\hline \multirow[t]{4}{*}{ Mechanical errors } & Spelling & 220 & 96.5 & 8 & 3.5 \\
\hline & Capitalization & 172 & 75.4 & 56 & 24.6 \\
\hline & Punctuation & 176 & 77.2 & 52 & 22.8 \\
\hline & Total & 228 & 100 & 0 & 0 \\
\hline
\end{tabular}

From the table, the students committed eight sub-types of intralingual errors namely, overgeneralization, omission, addition, simplification of parts of speech, misinformation, agreement, verb forms and mechanical errors. 


\section{DISCUSSION}

It can be observed that the intralingual errors committed by the students in their essays in French cover different aspects of the French language which, according to Shaffer (2009), vary according to how the surface structure of a sentence or expression is altered by the error. The finding on students' errors of overgeneralization agrees with Touchie (1986), that overgeneralization involves extending the use of one form or construction in one context to other contexts where it should not apply. The finding agrees with past findings in language learning like those of Wu and Garza (2014), who found that students committed errors of overgeneralizations due to partial exposure to the target language. It also agrees with Arachchi (2015), who found students' errors to include overgeneralization of known language rules and so on. The presence of errors of overgeneralization in students' essays shows that the students are yet to master the French language structures to the level of using it for communication, which is why French was included in the curriculum. It is interesting to observe that the students are aware of French language rules, which guide the construction of sentences in French. An example of such a rule is placing an adjective after the noun it qualifies. Sadly, it is also observed that the students have not learnt the exceptions to that rule as shown in the construction of the sentence II a troisenfantsbons(Literally, He has three children good). The sentence is faulty. Structurally, it follows the general French grammar rule of an adjective bons coming after the noun it qualifies, enfants. However, this is one of the exceptions to the rule, where adjectives come before nouns. Therefore, the sentence has an error of overgeneralization. The correct sentence should be II a troisbonsenfants. To overcome this type of error, the students need to learn the circumstances under which grammatical rules in French are used. If they fail to do so, they will not be able to communicate meaningfully in French.

The findings on the students' error of omission agree with past researches like Vásquez (2008), who found the error of omission in learners' language use as well as Mustafa, Kirana and BahriYs (2015), who found errors of omission among the learners' errors. However, in the findings of this study, the words omitted varied a bit from those omitted in the past researches. Whereas in the students' essays, the most common cases of omission were of verbs, prepositions and articles, Presada and La Badea
(2014) found that the most frequent errors of omission include the omission of the subjects in sentences. The findings on omission have serious implications on the students' use of French for oral or written communication. If, in their efforts to use French, students omit French words, it is doubtful that they can communicate meaningfully in French. They may make efforts to express themselves but their hearers or readers will not grasp correctly the message that they intend to communicate, due to the omission of some linguistic elements in the utterance. The omitted elements could be the ones carrying the greatest part of the intended message of the sentence. The following sentence is an example: II travaille IMSU (literally, He works IMSU). Looking closely at the sentence, it is obvious that something is missing in it. The verb in the sentence travaille (works) is not a transitive verb and, therefore, should not be directly followed by a noun. To be followed by a noun, there is need for another word to indicate the relationship between the verb and the noun. In this sentence, the noun, IMSU is a noun of location, a place, IMSU - abbreviation for Imo State University. Consequently, there is need for a preposition, at, indicating the relationship with the place of work. It means that the preposition, à is omitted in the sentence. With the omission, the meaning of the sentence could be that IMSU is an adverb, showing how he works, which does not make sense. The correct sentence should be: II travaille à IMSU. If the students continue to communicate in this way, there could be communication breakdown, in which case, the aims of studying French in Nigerian schools will not be realized.

The findings on errors of addition agree with the findings of Vásquez (2008) and those of Mustafa, Kirana and BahriYs (2015), who identified errors of addition in their researches. That the students committed errors of addition in writing essays in French implies that they have not learnt to communicate meaningfully in French. The following sentence is an example: Mon pèreest le professeur. Literally, the sentence is My father is the teacher. Grammatically, the sentence is correct. However, within this context, which is expressing the father's profession, French language does not accept the presence of an article before the name of the profession. Therefore, adding an article, le, in the above sentence is an error of addition, giving a different meaning to the sentence. The correct sentence is expected to be: Mon pèreest professeur. The effect of the error of addition in students' 
sentences is the failure to communicate meaningfully in French, as their utterances contain unwanted elements. To overcome such difficulty in communication, the students would need to be assisted to learn correct French structures. For instance, the teacher could make use of comprehension exercises, in both oral and written forms, to teach the students to learn and use the various aspects of the French language. The texts would need to be based on students' level of life experiences and exposure to French so that the students can follow with interest, as they are exposed to correct French structures.

The students' errors of simplification of parts of speech agree with those of Odo (2009), who found articles among leaners' errors and Mustafa, Kirana and BahriYs (2015), who found that the second most dominant types of errors were errors of articles. With errors of simplification of parts of speech, the students cannot communicate meaningfully in French since it is on these words that sentences are built. The following sentence is an example: II vient du Imo State. In the sentence, which literally means He comes from Imo State, the article used $\mathrm{du}$ is not appropriate here. This is because du is a masculine singular partitive article. Imo State is a noun of location and so requires a preposition to express that the father comes from there. The item required is from, which in French is de (d' before a vowel). Consequently, the correct sentence should be II vientd' Imo State.

With learning difficulties in the form of misinformation, students end up sending out wrong messages to their hearers and readers as illustrated by the sentence, Mon pèrepréfère de football. The literal translation of the sentence is My father prefers football. The error lies in the use of the word prefer, which implies liking something more than another. Here, the students used the verb without first presenting what is liked, to bring in the idea of comparison of level of likeness. The verb aimer (to like/love) would have been more appropriate. Therefore, the sentence should be Mon pèreaime le football. (My father likes/loves football). In using expressions like this, students would mean one thing and say or write another, thereby misinforming or confusing their hearer or reader.

The errors of agreement in the students' essays are in line with the findings Odo (2009), who found students' errors to include concord, that is, agreement and Chishiba and Mukuka (2012), who identified agreement errors among the learners' syntactic errors in French. For meaningful communication in French, there is need for agreement among the different parts of a sentence. The absence of such agreement in sentences end up confusing the hearers or readers of such sentences. An example is J'aime mon pays parce qu'elle est une bon pays. The literal meaning of the sentence is I love my country because it is a good country. The error in the sentence is the use of the pronoun elle, which is feminine in place of the entity, pays, which is masculine. Also, the use of the feminine article une to refer to a masculine noun, pays deepens the error of agreement. Therefore, the correct sentence should be J'aime mon pays parcequ'ilest un bon pays. Hence, in the use of expressions like this, there will not be meaningful communication in French.

The students' errors on verb forms agree with the research findings of Hanafi (2014) of wrong verb tenses. The implication of these errors is students' inability to communicate effectively in French. This is because a verb plays the important roles of expressing the state of being or the actions in a sentence. Moreover, verb conjugation is a dominant aspect of French grammar and errors in this aspect will affect the entire process of learning the language. An example is: Mon pèrepréfère mangeon banane. The literal translation of this sentence is My father prefers eating banana. The error in this sentence is that the main verb mangeon should have been in the infinitive, in line with the grammatical rule that after an auxiliary verb, like the verb préférer (to prefer), the main verb should be in the infinitive form. There is also an error of omission of a partitive article before the noun, banana. The correct sentence should be : Mon père préfère manger de la banane. For meaningful communication in French, the students must learn and master the rudiments of conjugation of verbs and the use of verbs in their various forms like tenses, numbers and other forms of verbs in French.

The findings students' mechanical errors agree with the findings of past researches in language learning like Jibowo (2002), who also found learners' errors in spelling, punctuation and use of capital letters; Odo (2009), who found students' errors to include spelling errors; Amara (2015), who also found spelling and capitalization errors and Chishiba and Mukuka (2012), who found errors of spelling, punctuation and the use of capital letters. The presence of mechanical errors in students' essays in French manifests some carelessness on the part of the students. Each of these errors can cause a breakdown in communication as meanings can be conveyed 
that are different from the intentions of the speaker or writer. In a piece of speech or writing, wrongly spelt words, wrongly punctuated sentences and indiscriminate use of capital letters can negatively influence communication as these can convey the wrong meaning to the hearers and readers. The negative difference that mechanical errors can make in communication is shown by the sentence: Le sud du Nigériaestborde par l'ocean Atlantique. The literal meaning of the sentence, Southern Nigeria is bounded by the Atlantic Ocean, has two spelling errors. The verb bord (bounded) does not have the é. Also, ocean is wrongly spelt; it should beocéan. Also, it should start with a capital letter because it is a particular ocean that is being referred to. The correct sentence should be Le Sud du Nigéria est bordé par l'Océan Atlantique. With errors like this, or a situation whereby a student starts a sentence with a small letter or starts a person's name in a small letter is a serious problem. It may even amount to negative attitude on the part of the students. Under such a situation, one wonders if the students of French can communicate meaningfully in the language. Therefore, students of French need to make efforts to learn the rules of the language, including the use of the different accents that form part of spellings of words, and manifest their learning of the language by using it to communicate in such a way as to correctly convey their intended messages.

It is not surprising that the students experienced difficulties from French. Delattre (2008) explains that the major difficulty from the French orthography is the ambiguity between the sound and writing systems in French. The author maintains that this causes irregularities in the spelling of French words. Also, Jung (2010) observes that the remarkable complexity of the French orthography is a cause of wrong organization of written ideas and poor spelling in the language. Consequently, as the learners of the language make efforts to surmount the challenges posed by words pronounced differently from the ways they are written, they commit intralingual errors. It is interesting that the learners are aware of the fact that they are the ones to acquire the language skills in French and so, they make every effort to express themselves in French, even when they make mistakes. A student's construction of a sentence like Mon pèremakéssuré des ilséndils child ... shows that the student wished to prove that the father makes sure that he sends his children to school, but lacked the vocabulary to express that. Realizing their lack of the vocabulary items, the student tried to make up for the lack by adding accents to the English words, in an effort to make them become French. Thus, in their difficulties, students form hypotheses about the language as well as strategies that enable them to wriggle out of their difficulties. Though the student applied a wrong strategy in the above sentence, the effort is commendable. To improve and sustain the students' efforts to learn French, teachers need to apply appropriate interactive strategies to correctly guide the students in their learning of the language.

The students' attempts to design their learning strategies show that they were active participants in the language learning process, able to construct language rules by themselves. The students were not there simply to repeat what the teacher tells them in class. On the contrary, the students were able to produce some utterances that they had never heard before. Consequently, the teachers of French need to assist the students in their efforts to learn language. The teachers are to adopt strategies that will boost the students' learning environment and encourage them to learn. The teachers can do this by building language instructions on real-life contexts by using strategies like authentic problems and tasks, discovery learning, group projects and discussions. These will help build language instructions on students' prior knowledge and experiences and make the language learning to be real and interesting to the students. In this way, they will be able to learn the French language as it is and overcome their intralingual errors.

\section{CONCLUSION}

The study analyzed junior secondary school students' intralingual errors in writing essays in French Language in the Basic Education Certificate Examination (BECE)in Imo State In 2015, 2016 and 2017. The results showed that the students committed eight sub-types of intralingual errors which include overgeneralization, omission, addition, 
simplification of parts of speech, misinformation, agreement, verb forms and mechanical errors. The errors were as a result of the difficulties which the students experienced from the target language, French.

\section{RECOMMENDATIONS}

Based on the findings of the study, the following recommendations are made:

1. Teachers of French need to build language instructions on students' prior knowledge and experiences, thereby making language learning to be real and interesting to them.

2. Teachers are advised to use instructional materials from the learners' immediate environment as that can help the students to learn French in real-life situations and so use words appropriately in communication.

3. Teachers of French are advised to expose their students to comprehension exercises that will help them to learn French words within particular contexts. This will enable the students to communicate their ideas with the appropriate French words.

4. Students of French are encouraged to be more careful when writing in French, to avoid errors of spelling, punctuation and other mechanical errors.

5. There is a need for teachers of French to groom the students in the parts of speech in French and how each of them functions in a sentence. This will enable the students to learn to use French words appropriately in sentences.

6. Teachers are advised to drill the students in basic French grammar. This will help the students to overcome various types of errors of French grammar.

7. The students are encouraged to exercise frequently the conjugation of verbs in French so they can overcome the errors of verb conjugation in French.

8. Teachers are encouraged to use interactive teaching strategies and activities in teaching French, to enable the learners use the language in communication in the class as well as outside the class.

9. Teachers are encouraged to use a lot of instructional materials for teaching French. That will help the students to correctly learn the confusing topics like use of prepositions and articles.
10. The teachers of French need to avail themselves of seminars and conferences on the different types of errors that students commit and the appropriate strategies to adopt in helping students overcome the errors.

\section{REFERENCES}

Amara, N., 2015. Errors correction in foreign language teaching. The Online Journal of New Horizons in Education, 5(3), 58-68 Retrieved from http://www.toined.net/journals/tojned/artic les/v05i03/v05i03-07.pdf on $23^{\text {rd }}$ January, 2018.

Arachchi, N. W., 2015. A linguistic study to identify writing errors in English: Based on year eleven students of Uva Province - Sri Lanka. International Journal of Science and Research (IJSR), 133-140.

Chishiba, G. M. and Mukuka, J., 2012. Native and second language interference in learning a second foreign language: The case of Bemba-speakers learning French in Zambia. African Higher Education Review (AHER), Vol. 6, July 2012, 100116.

Choroleeva, K., 2009. Language transfer: types of linguistic errors committed by Franco phones learning English as a second foreign language. Retrieved from www.hltmag.co.uk/oct09/mart02.rtf on $23^{\text {rd }}$ January, 2018.

Delattre, M., 2008. Impact de la régularité orthographique en production sous dictée. Paris: Centre national de la recherche scientifique. Retrieved from http://www.wwwcentrenatio naldelarecherchescientifique.comsitevisit ele/on $23^{\text {rd }}$ January, 2018. 
Duriau, V. J. Reger, R. K. and Pfarrer, M. D., 2007. A content analysis of the content analysis literature in organization studies: Research themes, data sources, and methodological refinements. Organization Research Methods, 10: 534. Retrieved from https://www.terry.uga.edu/management/c ontentanalysis/research/ on $13^{\text {th }}$ September, 2019.

Examination Development Centre, Owerri, 2018. Statistics Unit.

Federal Ministry of Education, 2012. Junior secondary education curriculum: French JSS 1-3. Abuja: Nigerian Educational Research and Development Council (NERDC).

Ellis, R., 2010. Learner errors and error analysis. Retrieved from https://www.slideshare.net/MelissaFerrer/ learner-errors-and-error-analysis on $23^{\text {rd }}$ January, 2018.

Fluent Flix Limited, 2018. Byhannahlamarque Awkward! 9 common French mistakes you don't have to make. Retrieved from https://www.fluentu.com/blog/french/com mon-french-mistakes/ on $8^{\text {th }}$ May, 2018.

Glottopedia, 2009. Error Analysis. Retrieved from http://www.glottopedia.org/index.php/Erro $r$ analysis on $23^{\text {rd }}$ January, 2018.

Hanafi, A., 2014. The second language influence on foreign language learners' errors: the case of the French language for Algerian students learning English as a foreign language. European Scientific Journal, Vol. 2, 1857-7431.

Huck, S. W., 2012. Reading statistics and research. Boston: Allyn and Bacon, Pearson Education, Inc.

Idaka, I. I. and Anagbogu, G., 2012. Research design. In A. J. Isangedighi (Ed). Essentials of research and statistics in education and social sciences, 64-77. Calabar: Eti-nwa Associates.
Jibowo, A. V., 2002. A heuristic analysis of some Nigerian undergraduates' problems in English Language. Nigerian Journal of Curriculum Studies, 9(2), 126-132.

Jung, L., 2010. Interview with JAFFRE Dictée et apprentissage. Retrieved from http://wwwbiienlire.com:sitevisitele23/10/ 2014 on $27^{\text {th }}$ August, 2018.

Khansir, A. A., 2012. Error analysis and second language acquisition. Theory and Practice in Language Studies, 2 (5), 1027 - 1032. Retrieved from http://www.academypublication.com/issu es/past/tpls/vol02/05/22.pdf on $20^{\text {th }}$ May, 2017.

Mazet, V., 2017. Ten common French grammar mistakes (and how to avoid them). Retrieved from http://www.dummies.com/languages/fren ch/ten-common-french-grammarmistakes-and-how-to-avoid-them/on $\quad 8^{\text {th }}$ May, 2018.

Mustafa, F., Kirana, M., and BahriYs, S., 2015. Errors in EFL writing by junior high students in Indonesia. International Journal of Research Studies in Language Learning, 6(1), 38-52 Retrieved from https://www.researchgate.net/publication/ 306346383 Errors in EFL writing by i unior high students in Indonesia on $23^{\text {rd }}$ January, 2018.

Odo, S. I., 2009. Analysis of written grammatical errors in French language committed by senior secondary school students. A thesis submitted to the Department of Arts Education, Faculty of Education, University of Nigeria, Nsukka. Retrieved from

http://www.unn.edu.ng/publications/files/i mages/ODO\%20IFEAYI\%20BAGROUN D\%20OF\%20THE\%20STUDY.pdf on $23^{\text {rd }}$ January, 2018.

Presada, D., and La Badea, M., 2014. The effectiveness of error analysis in translation. PortaLinguarum22, junio 2014, 49-59. Retrieved from http://www.ugr.es/ portalin/articulos/PL numero22/4\%20DIANA\%20PRESADA.p df on $23^{\text {rd }}$ January, 2018. 
Pourcel, N., 2000. Erreurs sur le passage de la phonie à la graphie. Montpelier: IUFM de l'academie de Montpellier.

Shaffer, D. E., 2009. Classifying language learning errors. The internet TEFL Journal September 2005, 58 (1-6). Retrieved from http://www.academia.edu/12197473/Clas sifying Language Learning Errors on $23^{\text {rd }}$ January, 2018.

Suzy, S., 2016. 10 French grammar mistakes you're probably making. Retrieved from https://takelessons.com/blog/frenchgrammar-mistakes-z04 on $28^{\text {th }}$ April, 2018.

Thought Co., 2017. Top 10 advanced French mistakes: common French mistakes made by advanced students. Retrieved from https://www.thoughtco.com/topadvanced-french-mistakes-1369441on $8^{\text {th }}$ May, 2018.
Touchie, H. Y., 1986. Second language learning errors their types, causes, and treatment. JALT Journal, 8 (I) 1986, 75-79. Retrieved from https://jalt-https://jaltpublications.org/sites/default/files/pdfarticle/art5_8.pdf on $10^{\text {th }}$ August, 2019.

Vásquez, D. A. L., 2008. Error Analysis in a Written Composition. Retrieved from http://www.scielo.org.co/scielo.php?script =sci arttext\&pid=S165707902008000200008 on $29^{\text {th }}$ August, 2017.

Wu, H., and Garza, E. V., 2014. Types and attributes of English writing errors in the EFL Context - A study of error analysis. Journal of Language Teaching and Research, 5(6), 1256-1262. Retrieved from http://www.academypublication.com/issu es/past/j|ltr/vol05/06/05.pdf on $29^{\text {th }}$ 